\title{
Risk Estimation as a Decision-Making Tool for Genetic Analysis of the Breast Cancer Susceptibility Genes
}

Jenny Chang-Claude ${ }^{1, \#}$, Heiko Becher ${ }^{1}$, Maria Caligo $^{2}$, Diana Eccles ${ }^{3}$, Gareth Evans ${ }^{4}$, Neva Haites ${ }^{5}$, Shirley Hodgson ${ }^{6}$, Pål Møller ${ }^{7}$, Bernhard H.F. Weber ${ }^{8}$, Dominique StoppaLyonnet $^{9}$ for the EC Demonstration Project on Familial Breast Cancer

${ }^{1}$ Deutsches Krebsforschungszentrum, Division of Epidemiology, Im Neuenheimer Feld 280, 69120 Heidelberg, Germany

${ }^{2}$ Department of Oncology, University of Pisa, via Roma 57, 56126 Pisa, Italy

${ }^{3}$ Wessex Clinical Genetic Services, Princess Ann Hospital, Coxford Road, Southampton SO16 5YA, UK

${ }^{4}$ Clinical Genetic Services, St. Mary's Hospital, Oxford Road, Manchester M13 OJH, UK

${ }^{5}$ Department of Medicine and Therapeutics, University of Aberdeen, Foresterhill, AB25 $2 Z D, U K$

${ }^{6}$ Genetics Centre, Guy's Hospital, St. Thomas Street, London SE1 9RT, UK

${ }^{7}$ Unit of Medical Genetics, The Norwegian

Radium Hospital, 0310 Oslo, Norway

${ }^{8}$ Institut für Humangenetik, 97074 Würzburg, Germany

${ }^{9}$ Service de Génétique Oncologique, Institut Curie, rue d'Ulm 26, 75231 Paris, France

\footnotetext{
\# Correspondence: Dr. Jenny Chang-Claude, Deutsches Krebsforschungszentrum, Division of Epidemiology, Im Neuenheimer Feld 280, 69120 Heidelberg, Germany, Tel.: +496221 422373, Fax: + 496221 422203, E-mail: j.changclaude@dkfz-heidelberg.de
}

\begin{abstract}
For genetic counselling of a woman on familial breast cancer, an accurate evaluation of the probability that she carries a germ-line mutation is needed to assist in making decisions about genetictesting.

We used data from eight collaborating centres comprising 618 families (346 breast cancer only, 239 breast or ovarian cancer) recruited as research families or counselled for familial breast cancer, representing a broad range of family structures. Screening was performed in affected women from 618 families for germ-line mutations in BRCA1 and in 176 families for BRCA2 mutations, using different methods including SSCP, CSGE, DGGE, FAMA and PTT analysis followed by direct sequencing. Germ-line BRCA1 mutations were detected in 132 families and BRCA2 mutations in 16 families. The probability of being a carrier of a dominant breast cancer gene was calculated for the screened individual under the established genetic model for breast cancer susceptibility, first, with parameters for age-specific penetrances for breast cancer only [7] and, second, with age-specific penetrances for ovarian cancer in addition [20]. Our results indicate that the estimated probability of carrying a dominant breast cancer gene gives a direct measure of the likelihood of detecting mutations in BRCA1 and BRCA2. For breast/ovarian cancer families, the genetic model according to Narod et al. [20] is preferable for calculating the proband's genetic risk, and gives detection rates that indicate a $50 \%$ sensitivity of the gene test. Due to the incomplete BRCA2 screening of the families, we cannot yet draw any conclusions with respect to the breast cancer only families.
\end{abstract}

KEYWORDS: genetic counselling, genetic risk assessment, familial breast cancer 


\section{INTRODUCTION}

The awareness of genetic predisposition to breast cancer has increased tremendously since the identification of the two highly penetrant breast and ovarian cancer genes, BRCA1 and BRCA2 [19,29]. Women with a family history of breast cancer are particularly concerned about their own risk, thus creating a greater demand for risk assessment and genetic counselling as well as for genetic testing. Mutations in BRCA1 or BRCA2 account for the majority of high risk families in which the segregation of a dominant high-penetrance susceptibility gene has quite clearly manifested itself in multiple cases of breast cancer over several generations of close relatives [13]. Only a small proportion of families with less striking family history and with isolated early onset breast cancer can also be attributed to mutations in these genes, except in founder populations with recurrent mutations $[1,10,14,16,18,21,28]$. Mutation screening of affected family members is the preferred method used to quantify risk in high risk families since the identification of a functionally relevant mutation will permit differentiation between gene carrier and non-gene carrier status and thus more accurate quantification of risk for unaffected family members. Women with an inherited mutation in either BRCA1 or BRCA2 have an equally high lifetime risk of about 80 percent for breast cancer, where BRCA1 confers a higher risk for ovarian cancer and BRCA2 for male breast cancer $[8,9,26]$. Those who are noncarriers in a family with an inherited mutation will have the population risk of developing breast cancer which is $8 \%-12 \%$ in western European countries. Screening for mutations is, however, still a technically demanding and labor-intensive task and gene testing is usually only offered to persons with a more than threefold increase in risk compared to the general population [15].

For genetic counselling about familial breast cancer, an accurate evaluation of the probability that a woman carries a mutation is needed before making decisions about genetic-testing. Some estimates of the prior probabilities for detecting a mutation in certain family types defined by number and age at diagnosis of breast and ovarian cancer were reported and have recently been updated $[13,23]$. However, they do not account for families which may actually be harbouring mutations in a highly penetrant susceptibility gene, but are presenting a family history that does not provide conclusive evidence for the involvement of such a gene. One commonly employed model for estimating breast cancer risk, specifically for women with a family history of the disease, is based on the Cancer and Steroid Hormone (CASH) study data set. Claus et al. [5] have used these data to construct detailed tables that predict the cumulative risk of breast cancer over a given time interval based on age at onset of one or two affected first- and/or second-degree relatives. However, the Claus tables do not consider the complete pedigree structure, i.e., the number and ages of unaffected relatives and the exact genealogical relationship between the proband and her affected relatives.

A more sophisticated method of risk prediction is implemented in the software package LINKAGE [17] and allows the estimation of the proband's genetic risk under a particular genetic model, given her family history. This calculation takes into account the entire pedigree information, including family size, relationships, ages and disease phenotypes of all members and has been shown to provide more accurate risk estimation particularly in families with smaller numbers of affected members [22]. The magnitude of the estimated genetic risks depends upon the assumed genetic model and can therefore vary appreciably when different penetrance estimates are used.

In a previous study of 60 families, we investigated whether the carrier probability calculated for the youngest affected member according to one genetic model is useful for identifying high-risk families and found that all families with detected BRCA1 mutations showed carrier probabilities above 0.6 [3]. We were therefore interested to apply the different models empirically to estimate the probability of carrying a breast cancer susceptibility gene for women with a family history of the disease and compare these estimates with the outcome of mutation 
screening in a larger series of families from cancer genetics clinics.

\section{MATERIALS AND METHODS}

\section{Families}

We used data from eight collaborating centres of a European Union Demonstration Project, four located in the United Kingdom (Aberdeen, London, Manchester, Southampton), and one each in France (Paris), Germany (Heidelberg), Italy (Pisa) and Norway (Oslo). Families were recruited as research families or counselled for familial breast cancer at the cancer genetics clinics or both. Different criteria for inclusion were used by each centre, thus the families represent a broad range of family structures. Detailed pedigree information was obtained through the proband (consultand) and, in some instances, extended through contact with related family members. All diagnoses of cancer were verified from pathology reports where possible. Blood samples were obtained from an affected proband (if the consultand) or an affected family member.

\section{Mutation analysis}

Screening for mutations in BRCA1 was performed in the affected proband or affected family member in each of the 618 families included in this study. Mutation screening in BRCA2 was completed in 176 of these families. Different screening methods were employed in the different laboratories to detect sequence variants and included single strand conformation polymorphism (SSCP), conformation-sensitive gel electrophoresis (CSGE), denaturing gradient gel electrophoresis (DGGE), fluorescent assisted missense analysis (FAMA), and protein truncation test (PTT). The entire coding sequence and exon-intron boundaries of the BRCA1 gene were amplified from genomic DNA using PCR. Each variant exon was then reamplified and analysed non-radioactively with an automatic sequencer. All analyses demonstrating mutations were repeated for verification. For other purposes of this study, only functionally relevant mutations were considered and individuals with missense mutations of unproven clinical significance were not considered "positive" for germ-line pathogenic mutations [6,25].

\section{Statistical analysis}

As a measure of genetic risk without genotype data, the probability of being a carrier of a mutant allele (BRCA1 or BRCA2 or other dominant genes) was calculated for the affected individual screened in each family under the established genetic model for breast cancer derived by Claus et al. [4] with the MLINK component of the linkage analysis package LINKAGE [17]. We performed the calculations first using the penetrance parameters employed by Easton et al. [7] and then using those adapted by Narod et al. [20] for the analysis of Breast Cancer Linkage Consortium data. Under the Easton model, breast cancer susceptibility is conferred by an autosomal dominant allele, with population frequency 0.0033 , such that breast cancer risk is $67 \%$ by age 70 years. Under the Narod model, breast cancer susceptibility confers a breast cancer cumulative risk that is $71 \%$ by age 70 years and an ovarian cancer cumulative risk that is $42 \%$ by age 70 years. To implement this model in LINKAGE, family members were assigned to either 14 liability classes [7] or 21 liability [20] defined by (i) affection status, (ii) site of cancer (breast or ovarian), and (iii) age at cancer diagnosis or at last observation, using the seven age groups $<30,30-39,40-49,50-59,60-$ $69,70-79$, and $\geq 80$ years. Unaffected males were assigned to the liability class of females unaffected up to age 29, approximately equivalent to being of unknown carrier status. Females affected with both breast and ovarian cancer and males affected with breast cancer were assigned to the liability class of females affected in the youngest age group, thus maximizing their probability of being gene 
carriers. Under the Easton model, females with ovarian cancer diagnosed at any age were also assigned to this liability class. The calculated carrier probability is supposed to predict the likelihood of finding either BRCA1 or BRCA2 mutations. Thus, we assumed a combined gene frequency of mutant BRCAx alleles of 0.0033, as in the CASH model derived by Claus et al. [4].

Frequencies and proportions of individuals with detected mutations were descriptively presented by grouping according to participating centre, family type and estimated carrier probability.

\section{RESULTS}

The 618 families studied included 346 families with female breast cancer only, 239 families with female breast and ovarian cancer and 17 families with only ovarian cancer. A further 12 breast cancer only and four breast and ovarian cancer families included male breast cancer (Table 1). The mean age at diagnosis in families was 46.3 years for female breast cancer (range between 19 and 79 years), 53.2 years for male breast cancer (range between 29 and 73 years) and 52.7 years for ovarian cancer (range between 14 and 80 years). Due to the different types of families recruited by the eight centres, the mean carrier probability of probands screened by each centre showed a range between 0.30 and 0.82 calculated with the Easton model and between 0.22 and 0.73 with the Narod model (Figure 1).

Germline mutations in BRCA1 were detected in 132 families $(21.4 \%)$ overall, and in 35 $(10.1 \%)$ families with female breast cancer only, $88(36.8 \%)$ breast-ovarian cancer families, 8 (47.1\%) families with ovarian cancer only and 1 $(8.3 \%)$ family with male breast cancer (Table 2). The majority of the mutations were chain terminating, including 95 frameshift deletions/insertions, 21 nonsense mutations, 4 splice variant mutations, and there were 12

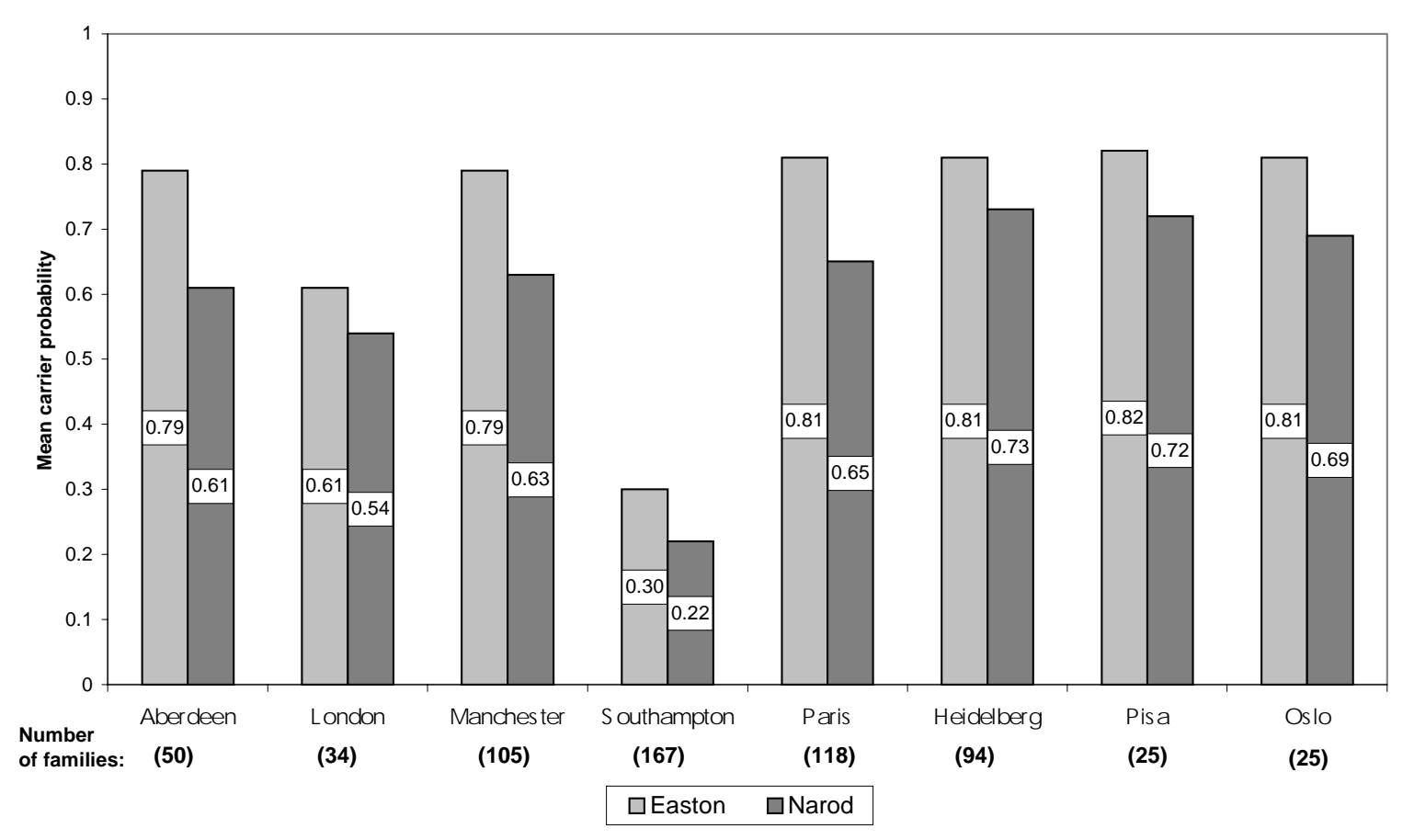

Fig. 1. A histogram of the mean carrier probability calculated for the screened patient under the genetic model according to (a) Easton et al. (1993) $\square$ and (b) Narod et al. (1995) $\square$ for each of the participating centres. 
Table 1

Distribution of families in different family types by participating centre ${ }^{a}$

\begin{tabular}{lrrrrrrrrr}
\hline Family type & All labs & ABD & LON & MAN & SOUTH & PARIS & HD & PISA & OSLO \\
\hline $\begin{array}{l}\text { BC only, female only } \\
\quad \text { No. of cases }\end{array}$ & & & & & & & & & \\
1 & 99 & 0 & 7 & 2 & 89 & 1 & 0 & 0 & 0 \\
$2-3$ & 158 & 15 & 19 & 12 & 63 & 17 & 19 & 9 & 4 \\
$4+$ & 89 & 11 & 2 & 18 & 2 & 14 & 31 & 5 & 6 \\
BC/OV, female only & & & & & & & & & \\
$\quad$ No. of cases & 2 & 0 & 0 & 0 & 0 & 2 & 0 & 0 & 0 \\
1 & 93 & 10 & 3 & 24 & 6 & 31 & 7 & 6 & 6 \\
$2-3$ & 14 & 8 & 3 & 41 & 5 & 45 & 32 & 3 & 7 \\
$4+$ & 17 & 3 & 0 & 8 & 0 & 2 & 0 & 2 & 2 \\
OV only & 12 & 2 & 0 & 0 & 2 & 4 & 4 & 0 & 0 \\
BC only, +male BC & 4 & 1 & 0 & 0 & 0 & 2 & 1 & 0 & 0 \\
BC/OV, +male BC & 618 & 50 & 34 & 105 & 167 & 118 & 94 & 25 & 25 \\
Total &
\end{tabular}

${ }^{a}$ ABD Aberdeen, LON London, MAN Manchester, SOUTH Southampton, HD Heidelberg

Table 2

BRCA1 and BRCA2 mutations detected in different family types (all centres)

\begin{tabular}{|c|c|c|c|c|}
\hline Family type & BRCA1 screened & BRCA1 mutation & BRCA2 screened & BRCA2 mutation \\
\hline \multicolumn{5}{|l|}{$\begin{array}{l}\text { BC only, female only } \\
\text { No. of cases }\end{array}$} \\
\hline 1 & 99 & 2 & 1 & 0 \\
\hline $2-3$ & 158 & 19 & 35 & 3 \\
\hline $4+$ & 89 & 14 & 48 & 4 \\
\hline \multicolumn{5}{|l|}{$\begin{array}{l}\text { BC/OV, female only } \\
\text { No. of cases }\end{array}$} \\
\hline $2-3$ & 93 & 29 & 34 & 1 \\
\hline $4+$ & 144 & 59 & 44 & 5 \\
\hline OV only & 17 & 8 & 3 & 0 \\
\hline $\mathrm{BC}$ only, +male BC & 12 & 1 & 9 & 2 \\
\hline $\mathrm{BC} / \mathrm{OV},+$ male $\mathrm{BC}$ & 4 & 0 & 4 & 1 \\
\hline & 618 & 132 & 176 & 16 \\
\hline
\end{tabular}

missense mutations considered to be functionally relevant. Of the families analysed for BRCA2, sixteen families harboured BRCA2 mutations, including 7 in breast cancer only families, 6 in breast-ovarian cancer families, and 3 in families with male breast cancer.

As expected the proportions of BRCA1 and BRCA2 mutations detected is higher in the higher ranges of carrier probability of the screened individual (Table 3). For breast cancer only families, BRCA1 mutations were detected in $34 \%$ or $26 \%$ (according to Easton or Narod model) of those who have a greater than $95 \%$ probability of carrying a mutant allele in a susceptibility gene whereas mutations were found in about 5\% among those with carrier probabilities less than $40 \%$. In the case of breastovarian families, BRCA1 mutations were detected in $48 \%$ or $49 \%$ (according to Easton or Narod model) of those with carrier probabilities above $95 \%$ and $25 \%$ or $16 \%$ of those with carrier probabilities below $40 \%$. The gradient of the proportion with BRCA1 mutations is apparent for breast cancer only families and does not differ for carrier probabilities according to the two genetic models. For breast-ovarian cancer families (including ovarian cancer only families), it appears that the carrier probabilities calculated 
Table 3

Detection of BRCA1 and BRCA2 mutations in families by carrier probability and family type

\begin{tabular}{|c|c|c|c|c|c|c|}
\hline \multirow{2}{*}{$\frac{\text { Carrier probability }}{\text { (range) }}$} & \multicolumn{3}{|c|}{ Breast only families } & \multicolumn{3}{|c|}{ Breast-ovarian families } \\
\hline & $\mathrm{n}$ & $\begin{array}{c}\text { BRCA1 mutations } \\
\mathrm{n}(\%)\end{array}$ & $\begin{array}{c}\text { BRCA2 mutations } \\
\text { n }(\%)\end{array}$ & $\mathrm{n}$ & $\begin{array}{c}\text { BRCA1 mutations } \\
\text { n }(\%)\end{array}$ & $\begin{array}{c}\text { BRCA2 mutations } \\
\mathrm{n}(\%)\end{array}$ \\
\hline \multicolumn{7}{|l|}{ Easton model } \\
\hline $0.95-1.0$ & 29 & $10(34)$ & $3(10)$ & 122 & $59(48)$ & $7(6)$ \\
\hline $0.9-0.95$ & 35 & $5(14)$ & $2(6)$ & 55 & $17(31)$ & 0 \\
\hline $0.8-0.9$ & 39 & $6(15)$ & $1(3)$ & 36 & $13(36)$ & 0 \\
\hline $0.6-0.8$ & 65 & $5(8)$ & $1(2)$ & 18 & $1(6)$ & 0 \\
\hline $0.4-0.6$ & 34 & $3(9)$ & $2(6)$ & 9 & $1(11)$ & 0 \\
\hline $0-0.4$ & 156 & $7(4)$ & 0 & 20 & $5(25)$ & 0 \\
\hline \multicolumn{7}{|l|}{ Narod model } \\
\hline $0.95-1.0$ & 34 & $9(26)$ & $4(12)$ & 77 & 38 (49) & $7(9)$ \\
\hline $0.9-0.95$ & 17 & $3(18)$ & $1(6)$ & 39 & $18(46)$ & 0 \\
\hline $0.8-0.9$ & 30 & $5(17)$ & 0 & 26 & $12(46)$ & 0 \\
\hline $0.6-0.8$ & 44 & $3(7)$ & $1(2)$ & 29 & $12(41)$ & 0 \\
\hline $0.4-0.6$ & 46 & $6(13)$ & $2(4)$ & 31 & $7(23)$ & 0 \\
\hline $0-0.4$ & 187 & $10(0.05)$ & $1(0.005)$ & 58 & $9(0.16)$ & 0 \\
\hline
\end{tabular}

using the Narod model correlate better with the proportion of BRCA1 mutations detected.

BRCA2 mutation analysis has not been completed for all families. Thus, although the largest proportion of mutations was detected in those who have carrier probabilities above $95 \%$, the correlation with decreasing carrier probability is not clearly discernible.

The graphs of the proportions of BRCA1 and BRCA2 mutations by smaller ranges of carrier probability show clearly that probability of detecting a gene mutation increases with increasing carrier probability, particularly in breast cancer only families (Figures 2 and 3).

When we consider only families with 4 or more breast cancer cases diagnosed under the age of 60 years, regardless of the occurrence of ovarian cancer, the carrier probability of the screened patient still ranges between 0.29 and 1.0 with a mean of 0.92 when using the Easton model and between 0.16 and 1.0 with a mean of 0.88 for the Narod model. The proportion of detected mutations is above $40 \%$ in patients with carrier probabilities greater than $95 \%$ and below $30 \%$ in those with carrier probabilities between $60 \%$ and $90 \%$ (Figure 4). Even in these families with multiple cases of breast cancer, there is clearly a correspondence between the proportion of mutations detected and the calculated carrier probability.

\section{DISCUSSION}

We investigated descriptively whether gene carrier probabilities, given family history, calculated for families referred to cancer genetics clinics, predicts the likelihood of finding a mutation in one of the breast cancer susceptibility genes. The series of families studied ranged from single early onset cases to large families with multiple affected members and reflects the type of families that could be counselled in any cancer genetics clinic. Several different techniques were used for mutation screening in this study. Since all these methods are conventionally employed at cancer genetics clinics and have similar reported sensitivity levels, we felt that the combined results could reflect the experience of other centres.

In the interpretation of the results, we are limited by the fact that mutation screening for BRCA2 was not completed in all families. Thus, the estimated proportion of mutations detected will always be lower than expected even when we take into account the sensitivity of the screening methods and the existence of further highly penetrant breast cancer susceptibility genes. Based on 237 families with at least four cases of breast cancers aged under 60 years at diagnosis collected by the Breast Cancer Linkage Consortium, Ford et al. [13] estimated that $80 \%$ 

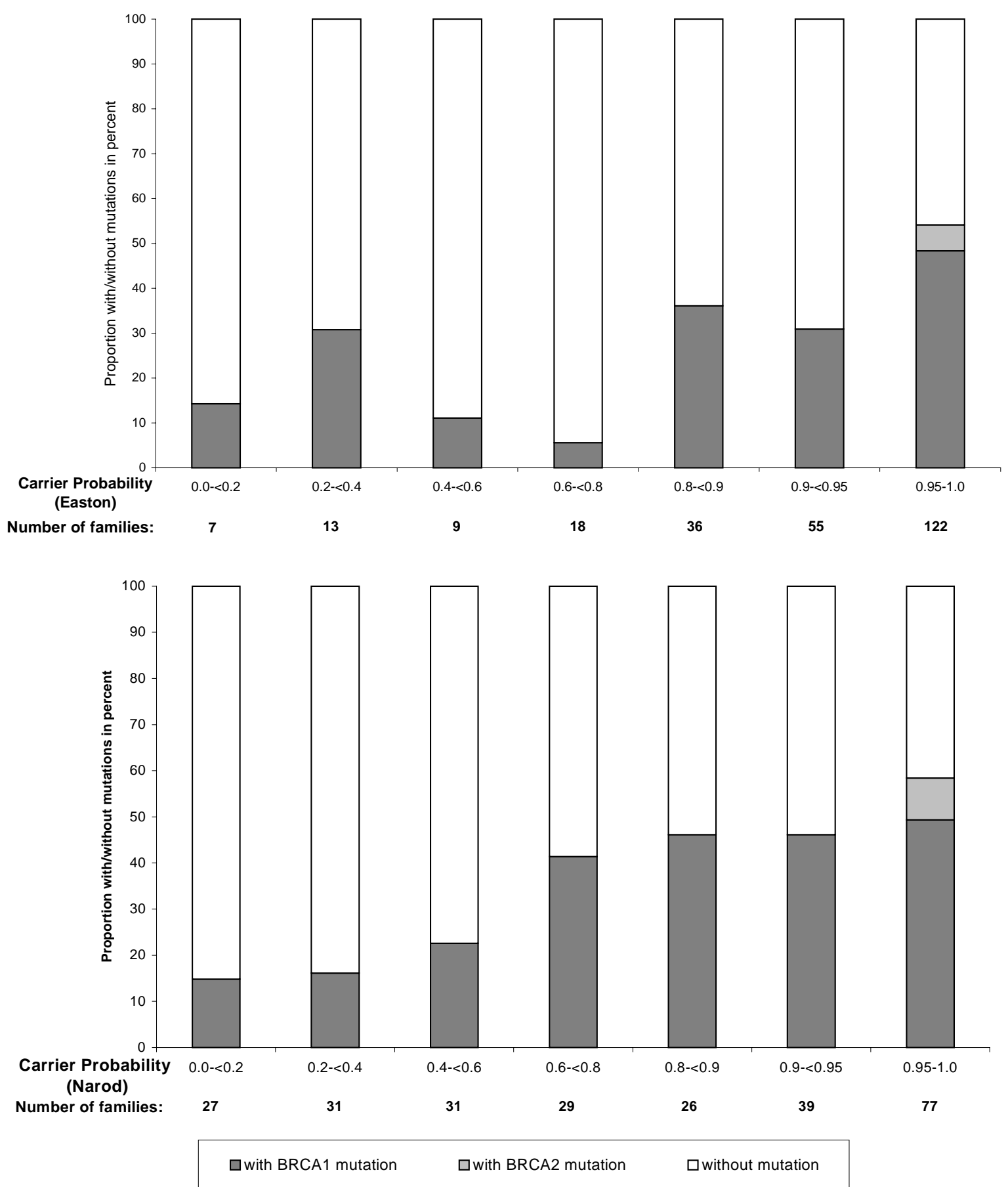

Fig. 2. Two histograms showing the proportion of (i) BRCA1 mutation $\square$, (ii) BRCA2 mutation $\square$ and (iii) without mutation $\square$ detected in screened patients from 260 "breast-ovarian cancer" families (including ovarian cancer only families) in different ranges of carrier probability calculated under the genetic model according to (a) Easton et al. (1993) and (b) Narod et al. (1995). 

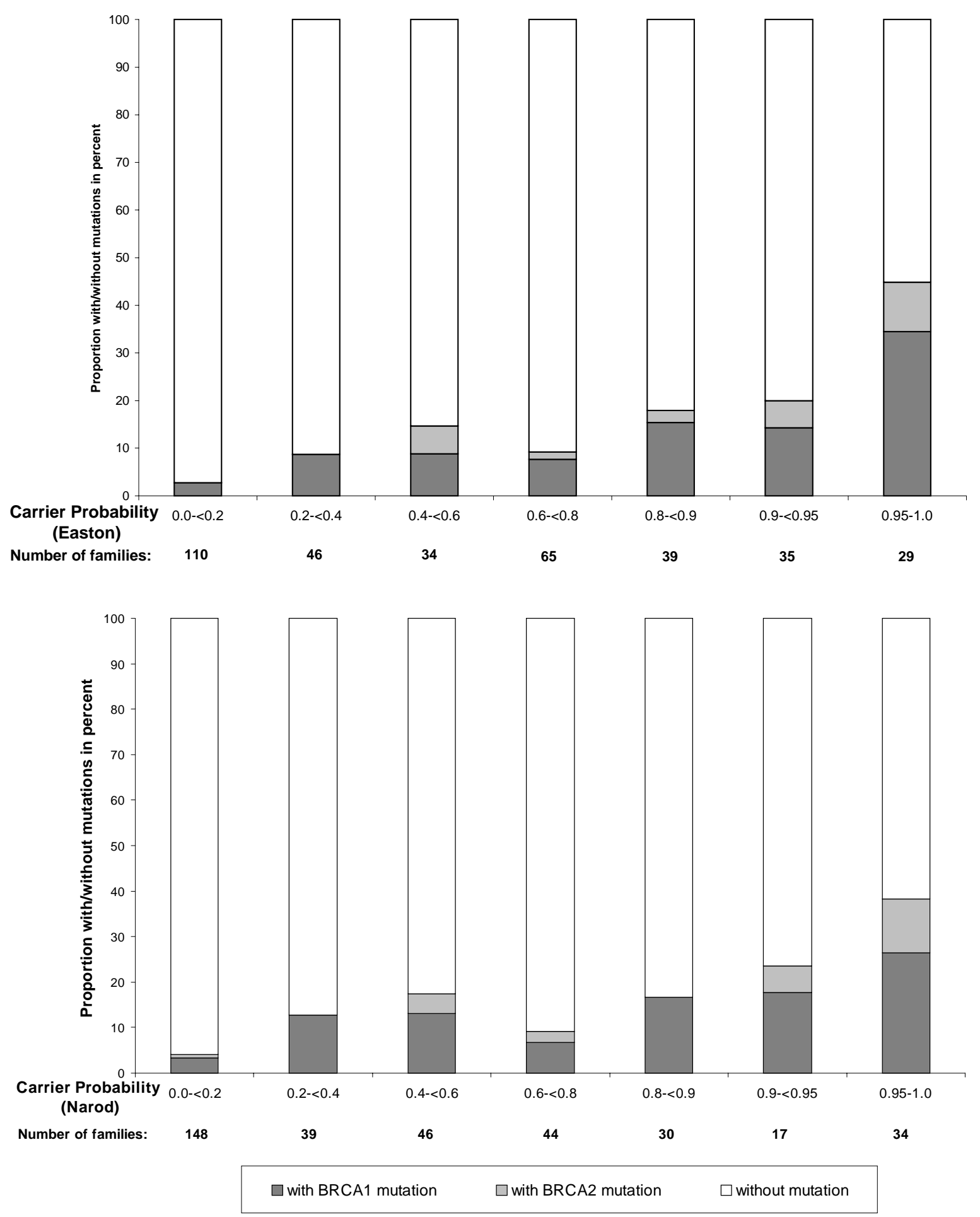

Fig. 3. Two histograms showing the proportion of (i) BRCA1 mutation $\mathbf{\square}$, (ii) BRCA2 mutation $\mathbf{\square}$ and (iii) without mutation $\square$ detected in screened patients from 358 "breast cancer only" families in different ranges of carrier probability calculated under the genetic model according to (a) Easton et al. (1993) and (b) Narod et al. (1995). 

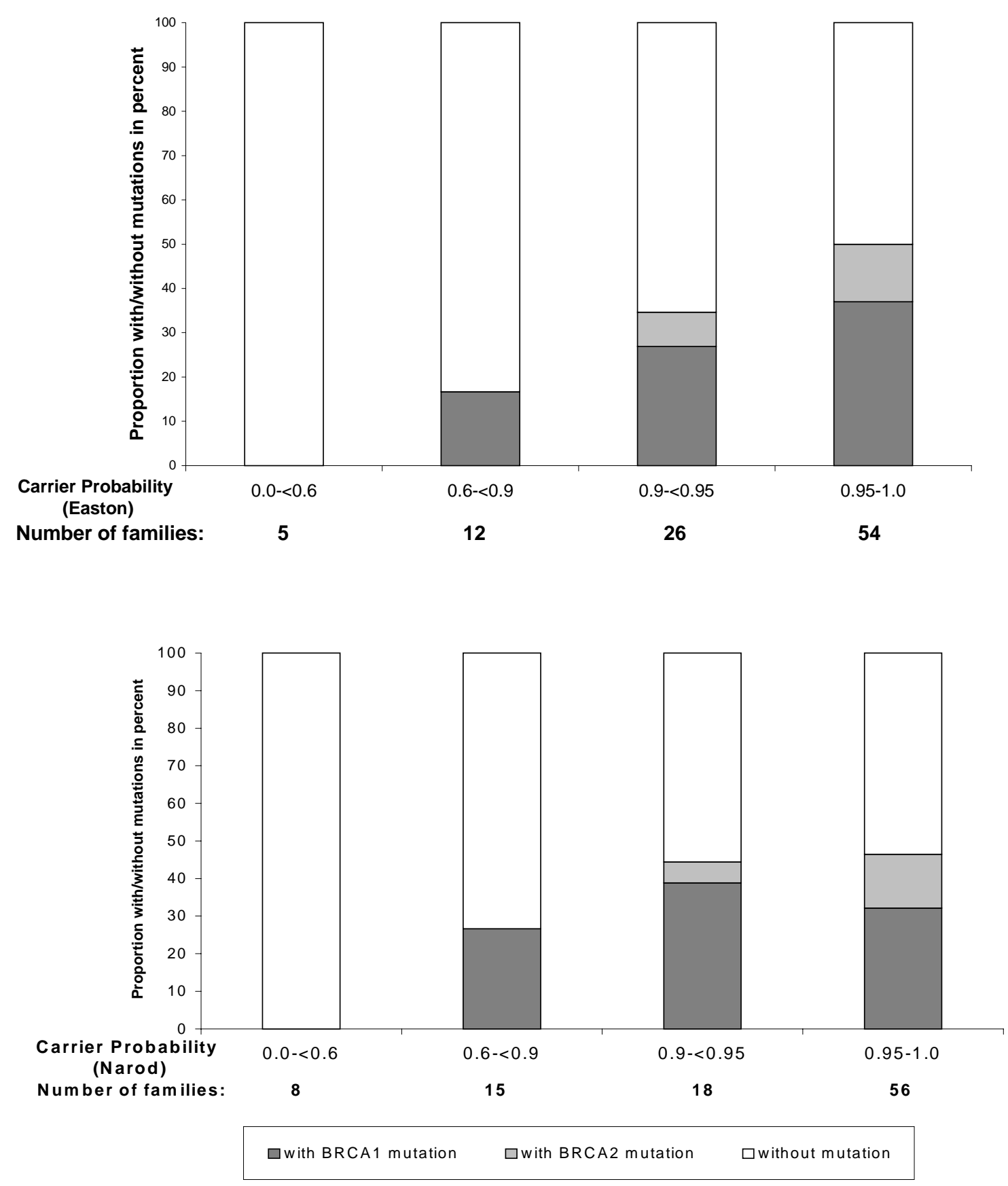

Fig. 4. Two histograms showing the proportion of (i) BRCA1 mutation $\square$, (ii) BRCA2 mutation $\square$ and (iii) without mutation $\square$ detected in screened patients from 97 families with four or more breast cancer cases under 60 years of age in different ranges of carrier probability calculated under the genetic model according to (a) Easton et al. (1993) and (b) Narod et al. (1995). 
of hereditary breast-ovarian cancer families are attributed to BRCA1 and $15 \%$ to BRCA2. For breast cancer only families, BRCA1 and BRCA2 contribute $28 \%$ and $37 \%$, respectively, with $35 \%$ unexplained by the identified genes. Since BRCA1 explains the majority of breast-ovarian cancer families, we can interpret our results more incisively with respect to the breast-ovarian cancer families rather than to the breast cancer only families.

For breast-ovarian cancer families, the correlation between the detection of a germ-line mutation in BRCA1 and the estimated probability of being carrier of a susceptibility gene for the screened proband is clearly better based on the genetic model according to Narod et al. [20]. This can be seen by noting that for each of the ranges of carrier probability, the proportion detected is approximately $50 \%$ of the mean carrier probability of that range, and this is relatively constant over all groups. For example, for the carrier probability range of 0.9 to 0.95 , the proportion of mutations detected was 0.46 (Table 3). This is not unexpected since the Narod model incorporates age-specific penetrances for ovarian cancer as well. This also indicates a sensitivity of the gene test of about $50 \%$. This corresponds to the expected detection rate if we assumed the estimated sensitivity of $63 \%$ and the contribution of BRCA1 to breastovarian cancer families of $80 \%$ from the data of the Breast Cancer Linkage Consortium [13]. Since these estimates are likely to be similar for ovarian cancer specific families [24], we included the ovarian cancer only families when examining the group of breast-ovarian cancer families.

For breast cancer only families, our present data do not show an apparent difference in the correlation between detecting a germ-line mutation in BRCA1 or BRCA2 and the estimated probability that the screened proband is a carrier of a susceptibility gene, based on the two genetic models employed. The two genetic models differ only in the age-specific penetrances of breast cancer whereby, in the Narod model, an older case of breast cancer is assigned a lower probability of being a carrier of a mutant gene. We cannot, however, draw any conclusions with respect to the breast cancer families before BRCA2 mutation screening is completed in a larger proportion of these families.

We show that the calculation of the probability of being carrier of a susceptibility gene is a more refined method of risk assessment when we focus on a set of families defined by number and age of affected family members. In the 97 high-risk families with four or more breast cancer cases diagnosed under the age of 60 years, there were 9 families in which the estimated carrier probability of the screened patient was below 0.6. Mutations in BRCA1 were not detected in any of these families. As we would have expected, the multiple cases in these families were more often second and third degree relatives of one another and less likely to be first degree related.

The estimation of the probability of being carrier of a dominant breast cancer susceptibility gene, given family history, provides a common measure for all types of families being counselled and gives a direct measure for the likelihood of detecting mutations in BRCA1 and BRCA2 if the contribution of these genes for the specific family type involved (breast cancer only or breast and ovarian cancer) is taken into account. For families with breast and ovarian cancer occurrence, the Claus model with parameters according to Narod et al. [20] is the preferred genetic model for the calculation of the proband's genetic risk. As we have discussed previously, the carrier probability can be reduced considerably when the correlation between phenotypes and genotypes is imperfect [3]. For the computation, this situation arises not only with incomplete penetrance of the genotype but also when an obligate carrier is affected with other cancers which are known to be BRCA1 or BRCA2 associated but which are not accounted for in the assumed genetic model $[2,9,11,27]$. Therefore, the accuracy of the estimated carrier probability as a measure of genetic risk will always depend upon the accuracy of the pedigree data and the assumed genetic model. 
At present, it is not possible to derive gene specific risks using the LINKAGE software employed. Estimates of gene frequency of BRCA1 and age-specific penetrances for BRCA1 and BRCA2 are available and estimates of gene frequency for BRCA2 are being generated from several population-based studies $[10,12$, $13,28]$. In the future, we shall be able to evaluate the usefulness of estimates of gene specific risks for decision-making in genetic diagnosis.

\section{Acknowledgments}

We would like to thank all the families for their participation, the clinicians and pathologists for their co-operation in collecting the material and our colleagues, Michael Steel, Hans Vasen, Generoso Bevilacqua and Patrick Morrison, for their collaboration. We would also like to thank Kati Smit for excellent documentation and data management. This work was made possible by funding of a European Community Demonstration Project.

\section{References}

[1] Andersen, T.I., Borresen, A.L. and Møller, P. A common BRCA1 mutation in Norwegian breast and ovarian cancer families? [letter] Am. J. Hum. Genet. 59, (1996) 486-487.

[2] Berman, D.B., Costalas, J., Schultz, D.C., Grana, G., Daly, M. and Godwin, A.K. A common mutation in BRCA2 that predisposes to a variety of cancers is found in both Jewish Ashkenazi and non-Jewish individuals. Cancer Res. 56, (1996) 3409-3414.

[3] Chang-Claude, J., Dong, J., Schmidt, S., Komitowski, D., Becher, H., Stratton, M.R. and Royer-Pokora, B. Using gene carrier probability to select high-risk families: Identification and characterization of German families with germline BRCA1 mutations. J. Med. Genet. 35, (1998) $116-121$.

[4] Claus, E.B., Risch, N. and Thompson, W.D. Genetic analysis of breast cancer in the cancer and steroid hormone study. Am. J. Hum. Genet. 48, (1991) 232-242.
[5] Claus, E.B., Risch, N. and Thompson, W.D. Autosomal dominant inheritance of early-onset breast cancer. Cancer 73, (1994) 643-651.

[6] Durocher, F., Shattuck-Eidens, D., McClure, M., Labrie, F., Skolnick, M.H., Goldgar, D.E. and Simard, J. Comparison of BRCA1 polymorphisms, rare sequence variants and/or missense mutations in unaffected and breast/ovarian cancer populations. Hum. Mol. Genet. 5(6), (1996) 835-842.

[7] Easton, D.F., Bishop, D.T., Ford, D., Crockford, G.P. and the Breast Cancer Linkage Consortium. Am. J. Hum. Genet. 52, (1993) 678-701.

[8] Easton, D.F., Ford, D. and Bishop, D.T. Breast and ovarian cancer incidence in BRCA1mutation carriers. Breast Cancer Linkage Consortium. Am. J. Hum. Genet. 56, (1995) 265271.

[9] Easton, D.F., Steele, L., Fields, P., Ormiston, W., Averill, D., Daly, P.A., McManus, R., Neuhausen, S.L., Ford, D., Wooster, R., CannonAlbright, L.A., Stratton, M.R. and Goldgar, D.E. Cancer risks in two large breast cancer families linked to BRCA2 on chromosome 13q12-13. Am. J. Hum. Genet. 61(1), (1997) 120-833.

[10] Fodor, F.H., Weston, A., Bleiweiss, I.J., McCurdy, L.D., Walsh, M.M., Tartter, P.I., Brower, S.T. and Eng, C.M. Frequency and carrier risk associated with common BRCA1 and BRCA2 mutations in Ashkenazi Jewish breast cancer patients. Am. J. Hum. Genet. 63(1), (1998) 45-51.

[11] Ford, D., Easton, D.F., Bishop, D.T., Narod, S.A., Goldgar, D.E. and the Breast Cancer Linkage Consortium. Risks of cancer in BRCA1mutation carriers. The Lancet 343, (1994) 692695.

[12] Ford, D., Easton, D.F. and Peto, J. Estimates of the gene frequency of BRCA1 and its contribution to breast and ovarian cancer incidence. Am. J. Hum. Genet. 57, (1995) 14571462.

[13] Ford, D., Easton, D.F., Stratton, M., Narod, S., Goldgar, D., Devilee, P., Bishop, D.T., Weber, B., Lenoir, G., Chang-Claude, J., Sobol, H., Teare, M.D., Struewing, J., Arason, A., Scherneck, S., Peto, J., Rebbeck, T.R., Tonin, P., Neuhausen, S., Barkardottir, R., Eyfjord, J., Lynch, H., Ponder, B.A., Gayther, S.A., ZeladaHedman, M. et al. Genetic heterogeneity and penetrance analysis of the BRCA1 and BRCA2 genes in breast cancer families. Am. J. Hum. Genet. 62(3), (1998) 676-689. 
[14] Frank, T.S., Manley, S.A., Olufunmilayo, I., et al. Sequence analysis of BRCA1 and BRCA2: Correlation of mutations with family history and ovarian cancer risk. J. Clin. Onc. 16, (1998) 2417-2425.

[15] Gayther, S.A. and Ponder, B.A. Mutations of the $B R C A 1$ and BRCA2 genes and the possibilities for predictive testing Mol. Med. Today 3(4), (1997) 168-174.

[16] Johannesdottir, G., Gudmundsson, J., Bergthorsson, J.T., Arason, A., Agnarsson, B.A., Eiriksdottir, G., Johannsson, O.T., Borg, A., Ingvarsson, S., Easton, D.F., Egilsson, V., Barkardottir, R.B. High prevalence of the 999del5 mutation in Icelandic breast and ovarian cancer patients. Cancer Res. 56, (1996) 36633665.

[17] Lathrop, G.M., Lalouel, J.M., Julier, C. and Ott, J. Strategies for multilocus linkage analysis in humans. Proc. Nat. Acad. Sci. USA 81, (1984) 3443-3446.

[18] Malone, K.E., Daling, J.R., Thompson, J.D., O'Brien, C.A., Francisco, L.V. and Ostrander, E.A. BRCA1 mutations and breast cancer in the general population: analyses in women before age 35 years and in women before age 45 years with first-degree family history. J. Am. Med. Assoc. 279(12), (1998) 922-929.

[19] Miki, Y., Swensen, J., Shattuck-Eidens, D., Futreal, P.A., Harshman, K., Tavtigian, S., Liu, Q., Cochran, C., Bennett, L.M., Ding, W., Bell, R., Rosenthal, J., Hussey, C., Tran, T., McClure, M., Frye, C., Hattier, T., Phelps, R., HaugenStrano, A., Katcher, H., Yakumo, K., Gholami, Z., Shaffer, D., Stone, S., Bayer, S., Wray, C., Bogden, R., Dayananth, P., Ward, J., Tonin, P., Narod, S., Bristow, P.K., Norris, F.H., Helvering, L., Morrison, P., Rosteck, P., Lai, M., Barrett, J.C., Lewis, C., Neuhausen, S., Cannon-Albright, L., Goldgar, D., Wiseman, R., Kamb, A. and Skolnick, M.H. A strong candidate for the breast and ovarian cancer susceptibility gene BRCA1. Science 266, (1994) 66-71.

[20] Narod, S.A., Ford, D., Devilee, P., Barkadottir, R.B., Lynch, H.T., Smith, S.A., Ponder, B.A.J., Weber, B.L., Garber, J.E., Birch, J.M., Cornelis, R.S., Kelsell, D.P., Spurr, N.K., Smyth, E., Haites, N., Sobol, H., Bognon, Y.-J., ChangClaude, J., Hamann, U., Lindblom, A., Borg, A., Piver, M.S., Gallion, H.H., Struewing, J.P., Whittemore, A., Tonin, P., Goldgar, D.E., Easton, D.F. and the Breast Cancer Linkage Consortium. An evaluation of genetic heterogeneity in 145 breast-ovarian cancer families. Am. J. Hum. Genet. 56, (1995) 254264.

[21] Newman, B., Mu, H., Butler, L.M., Millikan, R.C., Moorman, P.G. and King, M.C. Frequency of breast cancer attributable to BRCA1 in a population-based series of American women. $J$. Am. Med. As. 279(12), (1998) 915-921.

[22] Schmidt, S., Becher, H. and Chang-Claude, J. Breast cancer risk assessment: Use of complete pedigree information and the effect of misspecified ages at diagnosis of affected relatives. Hum. Genet. 102, (1998) 348-356.

[23] Shattuck-Eidens, D., McClure, M., Simard, J., Labrie, F., Narod, S., Couch, F., Hoskins, K., Weber, B., Castilla, L., Erdos, M., Brody, L., Friedman, L., Ostermeyer, E., Szabo, C., King, M.-C., Jhanwar, S., Offit, K., Norton, L., Gilewski, T., Lubin, M., Osborne, M., Black, D., Boyd, M., Steel, M., Ingles, S., Haile, R., Lindblom, A., Olsson, H., Borg, A., Bishop, T., Solomon, E., Radice, P., Spatti, G., Gayther, S., Ponder, B., Warren, W., Stratton, M., Liu, Q., Fujimura, F., Lewis, C., Skolnick, M.H. and Goldgar, D.E. A collaborative survey of 80 mutations in the BRCA1 breast and ovarian cancer susceptibility gene. Implications for presymptomatic -testing and screening. J. Am. Med. As. 273, (1995) 535-541.

[24] Steichen-Gersdorf, E., Gallion, H.H., Ford, D., Girodet, C., Easton, D.F., DiCioccio, R.A., Evans, G., Ponder, M.A., Pye, C., Mazoyer, S., Noguchi, T., Karengueven, F., Sobol, H., Hardouin, A., Bignon, Y.-J., Piver, M.S., Smith, S.A. and Ponder, B.A.J. Familial site-specific ovarian cancer is linked to BRCA1 on 17q12-21. Am. J. Hum. Genet. 55, (1994) 870-875.

[25] Stoppa-Lyonnet, D., Laurent-Puig, P., Essioux, L., Pages, S., Ithier, G., Ligot, L., Fourquet, A., Salmon, R.J., Clough, K.B., Pouillart, P., BonaitiPellie, C. and Thomas, G. BRCA1 sequence variations in 160 individuals referred to a breast/ovarian family cancer clinic. Institut Curie Breast Cancer Group. Am. J. Hum. Genet. 60(5), (1997) 1021-1030

[26] Stratton, M.R. Recent advances in understanding of genetic susceptibility to breast cancer. Hum. Mol. Gen. 5, (1996) 1515-1519.

[27] Thorlacius, S., Olafsdottir, G., Tryggvadottir, L., Neuhausen, S., Jonasson, J.G., Tavtigian, S.V., Tulinius, H., Ogmundsdottir, H.M. and Eyfjord, J.E. A single BRCA2 mutation in male and female breast cancer families from Iceland with 
varied cancer phenotypes. Nat. Genet. 13, (1996) 117-119.

[28] Thorlacius, S., Struewing, J.P., Hartge, P. et al. Population-based study of risk of breast cancer in carriers of BRCA2 mutation. Lancet 352, (1998) 1337-1339.

[29] Wooster, R., Bignell, G., Lancaster, J., Swift, S., Seal, S., Mangion, J., Collins, N., Gregory, S., Gumbs, C., Micklen, G., Barfoot, R., Hamoudi, R., Patel, S., Rice, C., Biggs, P., Hashin, Y.,
Smith, A., Connor, F., Ararson, A., Gudmundsson, J., Ficenec, D., Kelsell, D., Ford, D., Tonin, P., Bishop, D.T., Spurr, N.K., Ponder, B.A.J., Eeles, R., Peto, J., Devilee, P., Cornelisse, C., Lynch, H., Narod, S., Lenoir, G., Eglisson, V., Barkadottir, R.B., Easton, D.F., Bentley, D.R., Futreal, P.A., Ashworth, A. and Stratton, M.R. Identification of the breast cancer susceptibility gene BRCA2 [see comments]. Nature 378, (1995) 789-792. 


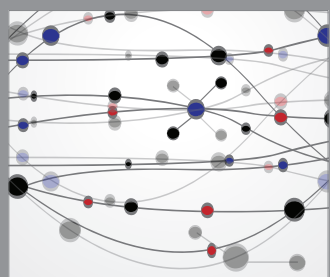

The Scientific World Journal
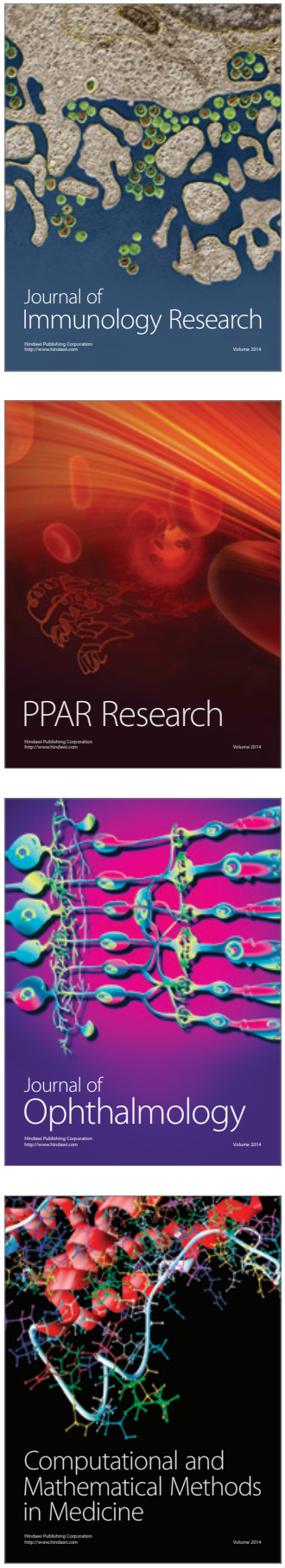

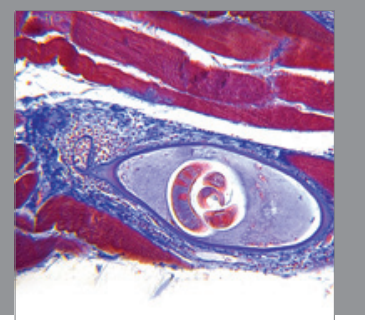

Gastroenterology

Research and Practice
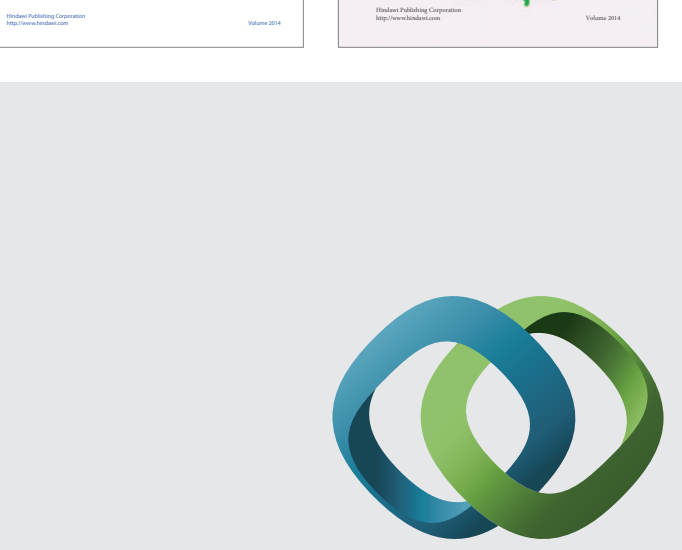

\section{Hindawi}

Submit your manuscripts at

http://www.hindawi.com
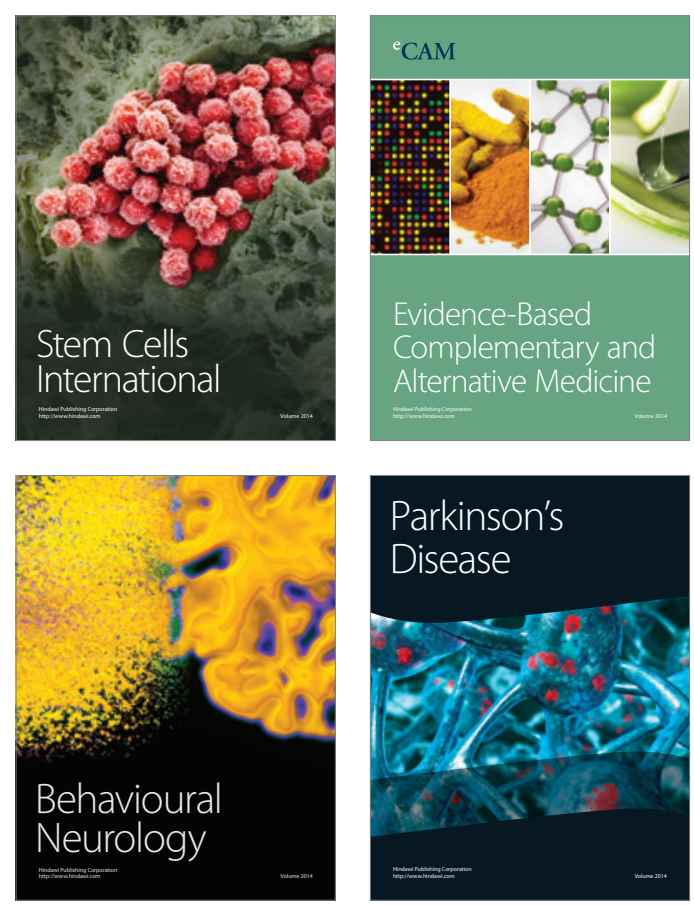

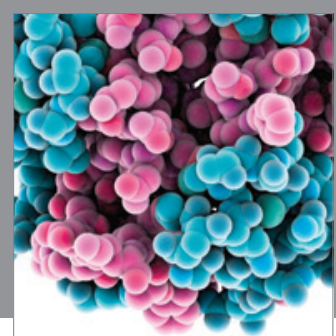

Journal of
Diabetes Research

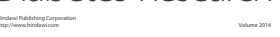

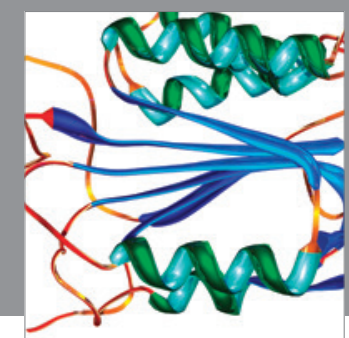

Disease Markers
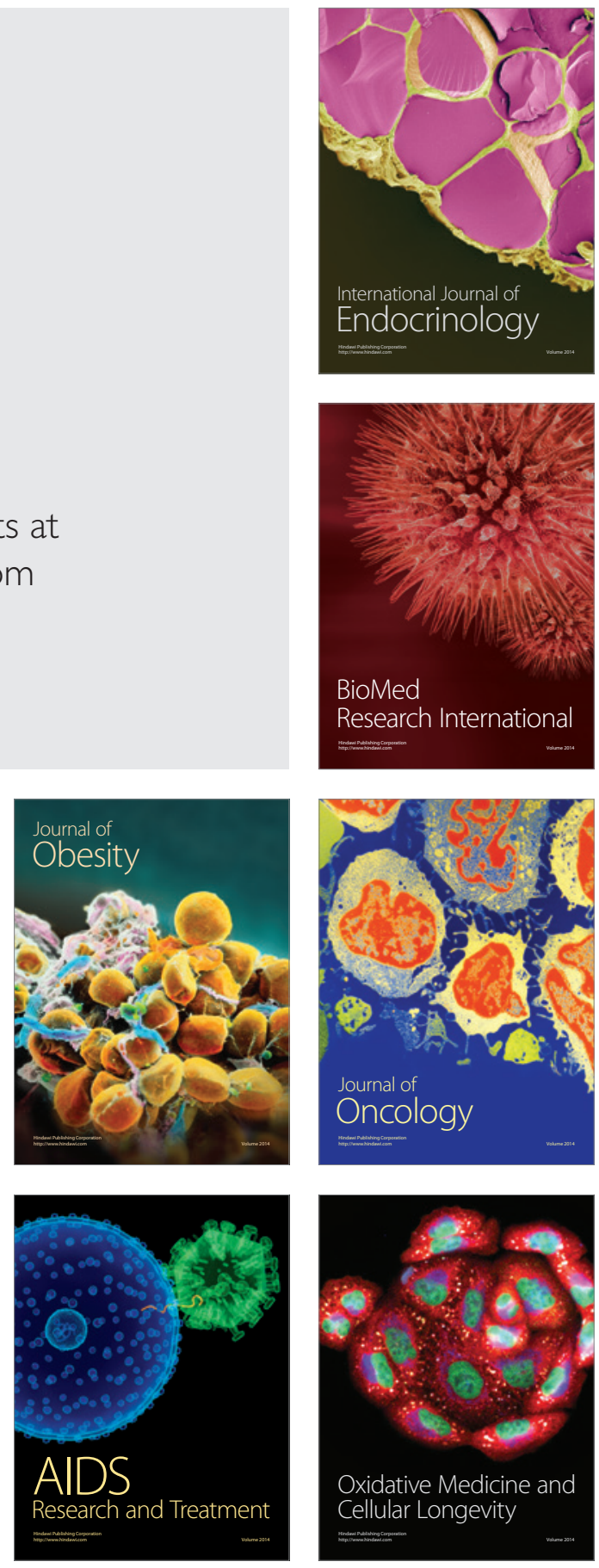